\title{
The Effectiveness of Co-Determination Laws in Cooperative and Adversarial Employment Relations: When Does Regulation Have Bite?
}

\section{Short title:}

Effectiveness of Co-Determination Laws: When Does Regulation Have Bite?

\author{
Uschi Backes-Gellner \\ (corresponding author) \\ Zurich University \\ Plattenstrasse 14, CH - 8032 Zürich \\ Switzerland \\ Phone: + 41 44-6344281 \\ Email: backes-gellner@business.uzh.ch
}

Jens Mohrenweiser,

Centre for European Economic Research

L7-1, 68161 Mannheim

Germany

Phone: +49 621-1235160

Email: Mohrenweiser@zew.de

\section{Kerstin Pull}

Tuebingen University, Nauklerstr. 47, 72076 Tübingen, Germany

Phone: +49 7071-2978186

EMail: Kerstin.Pull@uni-tuebingen.de 


\title{
The Effectiveness of Co-Determination Laws in Cooperative and Adversarial Employment Relations: When Does Regulation Have Bite?
}

\begin{abstract}
The German Codetermination Law grants workers of establishments with 200 or more employees the right to have a works councillor who is fully exempted from his or her regular job duties while still paid his or her regular salary. We analyse theoretically and empirically how this de jure right to exemptions translates into de facto practice, and we explicitly take into account the nature of the employment relations participation regime. We find that the right of exemption has no effect in cooperative employment relations because exemptions are granted even in the absence of legal rights, but does make a difference in adversarial relations when exemptions are only granted above the threshold where legal rights force employers to do so, i.e., legal rights do make a decisive difference in exactly those situations when the legislators' intent would not be realised without the right to legal enforcement.
\end{abstract}




\section{Introduction}

While the German Codetermination Law ${ }^{1}$ grants the right of exemption from all regular job duties for a works councillor in establishments with 200 or more employees, it is not clear whether this legal threshold of 200+ translates into a factual one. Until recently, the literature assumed an immediate "jump" at that legal threshold from zero to one in the probability that a works councillor is exempted from his or her regular job duties (see, e.g., Koller et al. 2008). However, as Mohrenweiser and Backes-Gellner (2010) recently showed in their empirical investigation this does not in fact occur. This raises the question whether such legal regulations do not have enough "bite” to fulfil the legislator’s intent of giving works councillors in larger enterprises more time to better perform their participatory tasks. ${ }^{2}$

In this paper, we argue that by explicitly taking into account the nature of the employment relationship we are able to provide a new explanation for this somewhat puzzling empirical result. We provide a theoretical model that takes into account that, in practice, managementworks council relations are heterogeneous, and that, as a result, the employment relations in a firm may either be more cooperative or more adversarial. ${ }^{3}$ Based on our model, we argue that in cooperative employment relations, works councillors will be exempted by their firms even in the absence of legal rights, and hence we should not observe an effect of the legal

\footnotetext{
${ }^{1}$ Codetermination Laws in Germany, and German works councils in particular, have received considerable attention in the industrial relations literature (see, e.g., Addison et al. 2004; Jirjahn and Smith 2006), but most of the work has concentrated on works council effects (see, e.g., Heywood and Jirjahn 2009a; Hirsch et al. 2010; Hübler and Jirjahn 2003; Mueller 2011) and - more recently - on the establishment of works councils (e.g., Jirjahn 2009; Mohrenweiser et al. 2012).

${ }^{2}$ Marsden (2012) shows that legal rights and actual participation patterns depend not only on the legal regulation but also on complementary factors at the firm level. He finds that legally based representative voice appears to act as a complement to individual voice. Conversely, voluntary voice tends to act as a substitute for individual voice. However, unlike our study, Marsden does not distinguish between different types of employment relations (cooperative versus adversarial) when looking at the relation between legal rights and actual participation patterns. To the contrary, Hann and Teague (2012), analysing the role of employment tribunals, come to the conclusion that the influence of law is steadily growing, and that legalistic and rights-based actions play a key role in the functioning of employment relations systems in Anglo-saxon countries - even in an arena where they should probably not play such a big role.

${ }^{3}$ Our distinction is similar to what Rolfsen (2011) calls traditional (employment) relations on the one hand vs. labour-management partnership on the other. Moreover, our theoretical analysis is motivated by Jirjahn and Smith (2006: 650) and Nienhueser (2009) who each argue that different employment relations may lead to very different outcomes.
} 
threshold. We rather expect a steady increase in exemptions with firm size-starting even in the smallest firms because it is in the employers' and the employees' best interest to do so to foster mutual gains from their employment relationship. To the contrary, in adversarial relations, we argue that exemptions will only be granted above the threshold where legal rights literally force employers to do so because employers are most concerned about protecting their share of the rent. Thus, there should be a strong exemption effect at the legal threshold in adversarial employment relations. I.e. only in a situation when the legislators' intent would not be realised without the right to legal enforcement we do expect legal rights to develop their bite. When empirically analysing the effectiveness of employment laws it is therefore absolutely crucial to distinguish between different types of employment relations because otherwise one would infer wrong conclusions on the effectiveness of labour regulations.

De jure, the German Codetermination Law states that while works councillor positions in general are intended to be uncompensated and honorary posts (§37 I BetrVG), larger-sized employers are required to release works council members from their job duties while continuing to pay their salaries "should it be necessary for proper fulfilment of their tasks when taking into consideration size and type of the establishment” (§37 II 1 2.HS BetrVG). Specifically, paragraph 38 BetrVG states that in establishments with 200 and more employees (the legal threshold), at least one member of the works council is to be put on a paid leave of absence. ${ }^{4}$ The number of works councillors to be put on paid leaves of absence then rises in accordance with establishment size. ${ }^{5}$

\footnotetext{
${ }^{4}$ The costs of a complete paid leave of absence for a works councillor at the threshold of 200 employees have been assessed by Schnabel and Wagner (2001) at 0.5\% of total salaries. Friedrich and Hägele (1997) calculate a rise of direct works council costs from 98,000 Euros to 148,000 Euros per year on average when the threshold was lowered from 300 to 200 employees.

${ }^{5}$ In addition, for a firm with 501-901 employees two works councillors have to be exempted, for a firm with 901-1,500 employees three works councillors, for a firm with 1,501-2,000 employees four works councillors, and for a firm with 2,001-3,000 employees five works councillors have to be exempted. From then on until a firm size of 10,000 employees, for every 1,000 additional employees one further works councillor has to be
} 
De facto, the law only grants a right to exemption but does not prescribe it and leaves the initiative to the firms and their works councils. Thus, the question is under what circumstance can we expect employers or employees to have an interest in exempting works councillors from their regular work and when do legal rights make a difference. Our theoretical analysis is based on a combination of the work by Freeman and Lazear (1995) on the one hand and Kotthoff $(1981,1994)$ on the other, supplemented by additionally taking firm size into consideration. The work by Freeman and Lazear is central to our analysis because it distinguishes between two very different effects of worker representatives: positive allocative effects on the one hand and (from the perspective of employers) negative distributive effects on the other. This distinction forms the very basis of our analysis. While, however, Freeman and Lazear do not elaborate on the conditions under which allocative effects might be particularly strong and distributive effects only weak (or vice versa), combining the work by Freeman and Lazear with the one from Kotthoff who explicitly distinguishes between different types of works councils and employment relations, allows us to do so: Specifically, we argue that in cooperative employment relations, allocative effects will be rather strong and distributive effects rather weak, while in adversarial employment relations it will be the other way around. Taking further account of a potential leverage effect with increasing firm size, allows us to derive our hypotheses on the exemption of works councilors in cooperative vs. adversarial employment relations below or above the legal threshold.

We empirically test our hypotheses using the works council data set of the Institute for Small- and Medium-Sized Enterprises (Bonn). Consistent with our theoretical hypotheses, we find that in adversarial employment relations, the probability of works councillor exemption jumps at the legal threshold: it is zero below the legal threshold, then sharply rises at the legal threshold and afterwards increases with firm size. But, as also expected from our

exempted. Starting with a firm size of more than 10,000 employees, for every 2,000 additional employees one further works councillor has to be exempted, 
theoretical analysis, in cooperative employment relations, we do not observe a jump in the probability of exemption at the legal threshold but rather observe a continuous increase with firm size. Hence, our results show that legal regulations, in our case the legal right of works councillor exemption, may have no effect when employment relations are cooperative, but will in fact make a decisive difference and will develop bite when employment relations are adversarial, i.e., when the legislators' intent would not be realised without the right to legal enforcement. Thus, even if voluntarism is fine in many cases-be it because firms grant workers' rights in their own interest or be it that the parties to the employment contract act in "the shadow of the law" (Bercusson 1994), in adversarial employment relations, the "bite" of an enforceable law is needed to make sure that workers' rights are really strengthened (if that is what the legislator wants).

While our analysis focuses on works councillor exemption, its implications go beyond this particular field of application. We find firms that voluntarily exempt works councillors from their regular responsibilities without legal obligation to do so and firms that fail to exempt works councillors in spite of a legal obligation to do so. For the former as well as for the latter, regulation apparently has no effect. Rather, the exemption of works councillors appears to depend on the nature of the employment relations participation regime - with regulation only, albeit reliably, affecting those firms where employment relations are adversarial. For all other firms, the probability of works councillor exemption steadily increases with firm size—-hinting at a general leverage effect, rather than legal forces, at work in firms with cooperative employment relations.

The structure of our article is as follows: First, we derive our theoretical hypotheses on the probability of exemption in cooperative versus adversarial employment relations for establishments below and above the legal threshold. Then, we present our empirical analysis. The final section concludes. 


\section{Theoretical Background and Hypotheses}

\subsection{Linking Works Councils Effects, the Nature of Employment Relations, and}

\section{Firm Size}

In their theoretical analysis of works councils, Freeman and Lazear (1995) differentiate between two potential works council effects, allocative and distributive. The allocative effects refer to works councils’ potential to increase the size of the pie or rent to be distributed, while the distributive effects refer to the share of the pie that each party receives.

Allocative effects have repeatedly been shown to exist (e.g., Addison et al. 2001, 2004; Hübler and Jirjahn 2003, or most recently for unions by Bryson, Forth and Laroche 2011) and can take several forms. Works councils might enhance intra-firm cooperation and communication by improving the information flow from employees to management and vice versa. They might legitimise management decisions, optimise production and business processes, and increase employee motivation, resulting in higher productivity and less fluctuation. Furthermore, works councils' information and co-determination rights might render management information more reliable and help articulate employee interests (Freeman and Lazear 1995; Mohrenweiser et al. 2012).

At the same time, distributive effects of works councils' activities have also repeatedly been shown to exist (Hübler and Jirjahn 2003; Mueller 2011; or for union distributive effects Bryson, Forth and Laroche 2011). Distributive effects do not influence the size of the pie to be distributed but rather the share of the pie that is allotted to the workers or left over for the employer. The employer's share might be reduced by improving working conditions, granting additional fringe benefits, pension funds, increasing on-the-job consumption (Heywood and Jirjahn, 2009a) or the like or as a result of the direct costs of work council activities (e.g., office space, election costs, etc.). Thus, although German works councils do not en- 
gage in regular wage bargaining, they can actively influence rent distribution by other means.

However, while we know from the sociological case study-based literature (beginning with Kotthoff 1981) that management-works councils relations are in practice heterogeneous and that employment relations participation regimes range from cooperative to adversarial, the potential interrelation between employment relations participation regimes, and their allocative and distributive effects has barely been analysed as yet. Among the notable exceptions are the studies by Dilger (2002, 2006) and - most recently - Pfeifer (2011a, 2011b) who each analyse whether the effects of works councils depend on works council "type”.

However, Freeman and Lazear do not take into account firm size as a determinant of the allocative versus distributive works council effects. In our theoretical explanation, we argue that both the nature of the employment relations participation regime and firm size are potential determinants of the allocative and distributive effects and discuss how the interrelation of these factors might impact whether works councillors are exempted from their regular duties or not.

First, regarding the nature of employment relations, we differentiate between two basic “types” of employment relations participation regimes: cooperative relations and adversarial, conflict-oriented ones. While, according to the analyses by Kotthoff $(1981,1994)$, in practice there will most certainly be more than two different "types" of works councils or employment relations participation regimes, we use this highly stylized categorization because of its methodological tractability. In cooperative relations, works councils are assumed to concentrate on activities that are apt to enlarge the pie to be distributed (trusting that in the end they will also receive a fair share of what has been generated). In adversarial relations, to the contrary, works councils will typically concentrate on securing a fair share of the rent rather than engaging in activities that might help increase the rent (which in the end will only accrue to 
the employer and not benefit the employees). ${ }^{6}$ Hence, we argue that in cooperative employment relations, works councils will typically concentrate on their allocative role, whereas in conflict-laden, adversarial employment relations, they will focus on distributive goals. While these assumptions would seem to be highly stylized, the recent empirical evidence gained by Pfeifer (2011a) supports this seemingly simplistic view.

Extending the argumentation by Pfeifer (2011a), we further argue that exempting works councillors from their regular job responsibilities (and granting them paid leaves of absence) will allow them to devote more time and energy to their activities and therefore more easily reach their respective goals. Hence, in cooperative employment relations, works councillors released from their regular job duties will invest more heavily in their allocative role, as they are more able to obtain detailed information and effectively exercise their rights to contribute to the common goal. However, works councillors who find themselves in conflict-laden employment relations will invest more heavily in their distributive role when exempted from their regular duties.

Second, with regard to the effect of firm size on works council effects, it seems plausible to assume that the potential for allocative effects in a cooperative environment increases with firm size as the result of a typical leverage effect: I.e., the more people cooperate and work together towards a joint goal, the greater the total effect, not only on the total rent, but also on the rent per employee. A single employee who increases cooperation with the employer will certainly have a positive effect; however, if 100 or 1,000 employees increase their cooperation, enhance their communication and work harder towards a joint goal, their total effect will be more pronounced and disproportionately greater. Hence, the allocative effects of works councils can be expected to disproportionally increase with firm size. While the rent

\footnotetext{
${ }^{6}$ Similarly, Bryson, Forth \& Laroche (2011) show that performance effects of unions also depend on institutional differences (which they study in an international comparison). Since in our data set all establishments are in one country we abstract from analysing such effects.
} 
per employee might well increase with firm size even in a situation without a works council (as a result of economies of scale, e.g.), in adversarial relations economies of scale might not be fully exploited. Further, there might be additional scale effects or other productivity enhancing effects resulting from cooperative employment relations where employees are willing and eager to boost the potential of a given technology. If employees are not cooperative, however, potential economies of scale cannot be fully exploited, and this loss will be larger the larger the firm. The evidence by Addison et al. (2001) that works councils’ positive allocative effects on firm productivity are especially found in larger establishment render empirical support to this view. ${ }^{7}$

Figure 1 illustrates the relation between firm size and works council effects for cooperative employment relations (panel A) and adversarial employment relations (panel B): In both types of employment relations participation regimes, the total rent per employee increases with firm size, so does the share of the total rent per employee which goes to the employer. However, in cooperative employment relations (panel A), the slope of the total rent per employee for any given firm size is larger than in adversarial relations as a result of the supportive works council. The total rent per employee increases more steeply with firm size because of the leverage effect resulting from more workers cooperating and enhancing allocative efficiency. In adversarial employment relations (panel B), to the contrary, works councillors neglect their allocative role (i.e. the total rent per employee is lower and increases less steeply in firm size) and rather concentrate on their distributive role resulting in a lower share of the rent per employee going to the employer as works councils in adversarial employment

\footnotetext{
${ }^{7}$ Of course, also transaction costs and frictions increase with firm size. However, this does not change our main argument but rather strengthens it because in a situation of increased transaction costs and friction losses due to diverging interests, it should become even more valuable for the firm to be able to bargain with employee representatives instead of having to bargain individually with a large number of increasingly diverse employees. Thus, in cooperative employment relations, having an effective works council will be more profitable for the employer the larger the firm. Since more and more heterogeneous employees obviously also means that a works councillor will have to invest more time in talking to more employees and finding out about their needs, this provides a strong incentive to the employer to exempt works councillors from their regular jobs even below the legal threshold - of course, only if employment relations are cooperative.
} 
relations use their power to secure a larger share of the rent for the workers. As a consequence, the employer's share of the rent per employee, i.e. the shaded area in Figure 1, is substantially lower for any given level of firm size in adversarial (panel B) than in cooperative employment relations (panel A), and it increases less steeply with firm size.

Figure 2 visualizes the hypothesized effects of exempting a works councillor from his regular job, again for the case of cooperative (panel A) and adversarial employment relations (panel B). In cooperative employment relations (panel A), exempting a works councillor from his or her regular job helps the works council to fulfil its productivity increasing allocative role and leads to a further increase in the total rent per employee and-as a consequence-also in the employer's share. Due to the leverage effect, the positive allocative effect resulting from works councillor exemption increases with firm size. ${ }^{8}$ Thus, firms in their own interest have an incentive to grant exemptions to their works councillors because their benefits due to the allocative effects are larger than their costs due to the distributive effect. This incentive gets stronger the larger the firm, i.e. the more there is to gain from the perspective of the employer. To the contrary, the exemption of a works councillor in adversarial employment relations (panel B) allows the works council to even more successfully pursue its distributive goals-leading to a further reduction in the employer share of an already smaller total rent per employee. Consequently, in adversarial employment relations, the employer does not have an incentive to voluntarily exempt works councillors from their regular jobs and will only do so when legally forced to.

\subsection{The Role of the Legal Threshold and Hypotheses}

\footnotetext{
${ }^{8}$ However, one might argue that not only the number of exempted works councillors increases with firm size, but also the number of non-exempted works councillors and that these non-exempted works councillors, too, will contribute to the positive allocative effects - in case employment relations are cooperative. The idea is that in cooperative employment relations, the exempted works councillors leverage the positive allocative potential of the other workers in general - and the positive allocative potential of their non-exempted co-works councillors in particular.
} 
According to legal regulations, there are two possibilities for whether and when a works councillor is exempted from his or her regular duties: (1) In firms with less than 200 employees, the employer has discretion to decide whether works councillors are granted paid leave; and (2) in firms with 200 or more employees, the employer must exempt at least one member of the works council from his or her regular tasks while continuing to pay his or her salary.

(I) Below the legal threshold of 200 employees where the firm can unilaterally decide whether to exempt a works councillor from his or her regular job, we expect to observe the following:

- $\quad$ In adversarial employment relations, exempting a works councillor is not advantageous for the employer because the works councillor will invest more in his or her distributive activities. Hence, firms will refrain from voluntarily exempting works councillors from their regular duties in adversarial employment relations.

- $\quad$ In cooperative employment relations, however, firms expect increasing returns with increasing firm size if works councillors are granted paid leaves of absence. The larger the firm, the greater the effect of a works councillor who is able to concentrate on his or her supportive activities and the higher the returns due to increasing allocative efficiency. In cooperative firms, the employer and the employees also find a cooperative way to share the resources; consequently, we expect a general pattern that the larger the firm, the greater the probability that a works councillor is exempted from his or her regular duties.

(II) At and above the legal threshold of 200 employees, employees and works councillors are in a position to exercise their right to exemption. We expect to observe the following: 
- In cooperative employment relations, the ability of works councillors to exercise their right to exemption has no effect because the employer generally benefits from granting a paid leave of absence with increasing firm size and will thus readily grant such leaves above the threshold. Thus, in cooperative employment relations, we will observe a further steady increase in the probability of exemption above the legal threshold.

- $\quad$ In adversarial employment relations, however, we expect the probability of works councillor exemption to increase drastically above the threshold because even if the employer will not exempt a works councillor from his or her regular duties, works councils will enforce their legal rights because doing so helps them obtain a larger share of the rent (as works councillors who can devote all their time to works council responsibilities are more effective in achieving this objective). As enforcing one's rights will still be costly, we do not expect the probability of exemption to jump to a probability of one instantly once the legal threshold is reached. Rather, above the threshold we anticipate a gradual increase in the probability of exemption with the size of the firm because the greater the number of employees, the higher the likelihood that additional shares of resources will make up for the costs of such battles to enforce these rights.

Thus, we make the following two hypotheses:

Hypothesis 1: In adversarial employment relations, the probability of exemption (a) is zero below the legal threshold, (b) "jumps" at the legal threshold, and (c) further increases with firm size above the legal threshold (see Figure 3). 
Hypothesis 2: In cooperative employment relations, the probability of exemption (a) does not "jump" at the legal threshold and (b) increases steadily with firm size over the whole firm size distribution (see Figure 4).

\section{Empirics}

\subsection{Data and Variables}

Data. We use a data set of the Institute for Small- and Medium-Sized Enterprises, IfM-Bonn. This cross-sectional data set is based on a manager survey on employment relations in general and works councils in particular in establishments with 20 to 500 employees from the year 2005. The data are representative of establishments of this size (for more details, cf. Schlömer et al. 2007). The data set is ideal to test our hypotheses due to its detailed information on codetermination and a large number of related questions on managerial issues. Particularly, our data set contains information on the incidence of works councillor exemption from their regular duties and the nature of the relationship between works councils and management. Given that we are interested in the determinants of paid leaves of absence for works councillors, but not on works councils per se, we restrict our data set to establishments with works councils, leaving 231 establishments for which we have information on all the variables that we use in our regressions.

Definition of variables. Table 1 gives the definitions and the descriptive statistics for our dependent variable as well as our explanatory and control variables.

As our dependent variable, we use a dummy variable indicating whether at least one works councillor is fully exempted from his or her regular tasks (works councillor exemption). ${ }^{94}$ In approximately $25 \%$ of the establishments in our sample works councillors are fully exempted from their regular duties.

\footnotetext{
${ }^{9}$ In addition to establishments with employees on "full” paid leaves of absence, there are also some establishments with employees on part-time leave. We include only "full” paid leave as our dependent variable for the
} 
One of our important explanatory variables is whether the establishment under consideration is below or above the legal threshold (200+ employees), above which a paid leave of absence is granted by law. Slightly over $43 \%$ of the establishments in the sample are above the legal threshold. In addition, we use the metric variable Insize to study size effects above and below the legal threshold (robustness checks are given below and in Table A1).

The variable bad employment relations is based on the question "How would you describe the relation between management and works council in your establishment” that participants answered on a Likert scale from "1" (very bad) to “5” (very good). As our data stems from IfM-Bonn survey of managers, the information on whether employment relations are judged to be rather good or bad refers to the managerial and not the works council perspective, which can be quite different as shown e.g. by Helfen and Schuessler (2009). However, for our research question this seems to be the perspective that is relevant. Since our research question focusses on the employer's decision to exempt or not to exempt a works councillor, the managerial perspective on the nature of the employment relation should be crucial. If management considers the employment relation to be cooperative, it is willing to grant rights voluntarily, but if it considers employment relations to be adversarial, it will not grant additional rights. For our empirical analysis, we created a dummy variable "bad employment relations” for establishments answering “1” (very bad) or “2” (bad). In our sample, approximately $11 \%$ of the establishments consider their employment relations to be bad $^{10}$ (see Table A2 in the Appendix for the distribution of the initial answers). ${ }^{11}$

\footnotetext{
following three reasons: (a) "part-time” leave may be minor, (b) we have no information on the number of leave hours, and (c) part-time leave is not subject to the legal regulations that interest us.

${ }^{10}$ Of course, this number is only to be seen as a snapshot at a given point of time. Descriptive statistics for 2013 would probably show other, maybe lower numbers as employment relations might have become more adversarial during the latest recessions.

${ }^{11}$ With reference to our basic theoretical assumption that in bad employment relations, works councils concentrate on their distributive role and less on their allocative one, we find the following: Confronted with the item “The works council improves the quality of decisions" hinting at a substantial allocative role of works councils, only $4 \%$ of managers in establishments with bad employment relations fully agree or agree, while more than $26 \%$ of managers in establishments with good employment relations fully agree or agree. In contrast, confronted with the item "The works council is a source of union strength" and highlighting the distributive role of
} 
Furthermore, we use a large number of control variables whose influence on works council incidence, attitude and effects (Addison et al. 1997; Jirjahn and Smith 2006) has been demonstrated in the past (for a complete list of variables used, cf. Table 1). Among others, we control for collective bargaining as this has been shown to influence both, allocative (Hübler and Jirjahn 2003) as well as distributive works council effects (Mueller 2011).

\subsection{Results}

Probit estimates. In this section, we analyse the determinants of works councillor exemption based on a series of probit models, with the likelihood of works councillor exemption as the dependent variable and 200+employees and/or Insize as explanatory variables, as well as the additional control variables from Table 1. Our empirical analyses start with a set of regressions for all firms (Table 2) to see whether there is a jump in paid leaves of absence at the legal threshold—as one would naively expect from a look at the de jure regulations. As long as we do not distinguish between good and bad employment relations there is no jump in the likelihood of paid leaves of absence for works councillors at the legal threshold (the coefficient of the variable "200+employees" is insignificant), which is in line with previous results not distinguishing between different types of employment relations.

However, if we split the sample and run separate regressions for good and bad employment relations, as suggested by our theoretical analysis, we come to different and more meaningful results and conclusions. When we first look at establishments with good employment relations (models II to IV in Table 2), we again find that there is no jump in the likelihood of works councillor exemption at the legal threshold (200+employees), which supports hypothesis 2a. Further, we find that the likelihood steadily increases with firm size

works councils, $48 \%$ of managers in establishments with bad employment relations fully agree, while a comparatively lower percentage of managers in establishments with good employment relations (28\%) fully agree. This result is mirrored in the overall evaluation of works councils as being either detrimental or beneficial. While $52 \%$ of managers in establishments with bad relations judge their works councils to be detrimental, less than $2 \%$ of managers in establishments with good relations do so. In total, the chosen operationalisation of "bad employment relations” hence seems to express our theoretical construct quite well. 
(InSize is significantly positive in models II, III and IV) and we find that the increase above the legal threshold is not larger than below the threshold (no significant coefficient of the interaction term between $200+$ employees and InSize in model IV), ${ }^{12}$ supporting hypothesis 2b. Thus we can conclude that whereas from a de jure perspective one would always expect exemptions to jump at the threshold, we find that de facto in cooperative employment relations, the probability of paid leaves of absence increases steadily with firm size over the entire firm size distribution - starting way below the threshold.

When we next look at firms with bad employment relations we find very different patterns. Looking at the descriptive distribution of works councillor exemption (cf. Table 3) one very obvious result is that there is no single establishment below the legal threshold that exempts at least one of their works councillors-although approximately half of the establishments with bad employment relations are below the legal threshold-which strongly supports hypothesis 1a. On the other hand, looking at probit estimations for the firms above the legal threshold (cf. Table 4$)^{13}$ we find that the coefficient of InSize is significantly positive, i.e. in adversarial employment relations above the legal threshold, the probability of exemption increases with firm size as stated in hypothesis 1c. Thus, there is a jump in the likelihood of paid leave of absence at the legal threshold, with a likelihood of zero below the threshold and a significantly positive increase in firm size above the threshold, which supports hypothesis 1c. Thus we can conclude that when looking at bad employment relations, we find that what we expect from a de jure perspective is congruent with what we observe de facto, i.e. the probability of paid leaves of absence is virtually zero below the legal threshold and makes a large jump at the legal threshold of 200 employees and grows steadily afterwards. Legal regulations develop their bite in adversarial employment relations and lead to a

\footnotetext{
${ }^{12}$ We show later that the marginal effects of the cross-derivate are indeed positive. Moreover, we undertook a series of robustness checks (see Table A1 in the Appendix) supporting our results.

${ }^{13}$ The regression contains only the twelve firms above the legal threshold, as there are no establishments with bad employment relations below the legal threshold that exempt works councillors from their regular duties.
} 
jump in exemptions as soon as the legal threshold is reached, while at the same time in cooperative employment relations there is no jump at the legal threshold.

To better illustrate these effects, we plot in figure 5 the predicted probabilities of works councillor exemption based on model III in Table $2 .{ }^{14}$ We see that in firms with bad employment relationships, the predicted probability of works councillor exemptions sharply increases above the threshold and reaches a likelihood of close to one in establishments with not even 400 employees. To the contrary, in firms with good employment relations the predicted probability of a works councillor exemption increases monotonically over the whole firm size distribution. The probability is approximately $15 \%$ in establishments with 150 employees, 30\% in establishments with 250 employees and 60\% in establishments with 400 employees. So overall, different types of employment relations make an economically important difference in works councillor exemptions. De jure one would expect a jump of exemptions at the legal threshold of 200, de facto we only observe such a jump for firms with bad employment relations.

Additionally, Figure 6 displays the raw descriptive results for the proportion of establishments exempting works councillors from their regular duties for all establishments (Panel A), establishments with bad relations (Panel B) and establishments with good relations (Panel C).

Robustness checks. To determine whether our result that there is no jump in the probability of a works councillor exemption in establishments with good relations is robust, we first ran a number of robustness checks with alternative specifications for firms with good

\footnotetext{
${ }^{14}$ We use the predicted probabilities because our preferred model entails interaction variables. Interpreting marginal effects of interaction variables in nonlinear models remains highly controversial. Marginal effects provide a sense of practical importance, but the functional form of a non-linear model implies that all explanatory variables have nonlinear effects on the probability of interest. Calculating marginal effects of interaction variables requires distributional assumptions. Therefore, we interpret the interaction effects with respect to the cross derivative of the underlying latent variable and, hence, focus solely on the statistical significance of the coefficient of the interaction variable (compare also Heywood and Jirjahn, 2009b for a discussion of this strategy).
} 
relations (cf. Table 5). We test several firm-size specifications and find robust effects. Only in the case when we exclude all but the legal threshold variable $200+$ employees, we find a significant effect for the legal threshold dummy. However, this effect only reflects that the average probability below the threshold is lower than the average probability above the threshold and thus only mirrors the result of the steady increase found in previous estimations that is now split into two parts: smaller firms with on-average lower probability of exemption and larger firms with on-average higher probability of exemption. Hence, above all, this result shows how a misspecification of the model may suggest an effect of a legal threshold that is in fact only a statistical artefact.

Second, we regress only the main explanatory variables (model 2 in Appendix Table A1) and further estimate a model that uses a set of covariates but excludes all other employment relations variables besides the variable for "bad employment relations" (model 3 in Appendix Table A1). As a further robustness check, model 1 in Appendix Table A1 uses an additional category for good or very good employment relations. In all of the regressions, the probability of a works councillor exemption increases with firm size, and the legal threshold has no effect.

As a final robustness check, we address the problem of a potential sample selection bias, as the existence of a works council may be endogenous and is most likely correlated with firm size (Jirjahn 2009; Mohrenweiser et al. 2012). To do so, we estimate a sample selection model fitting the determinants of the existence of a works council and the determinants of exemption (see Table A3 in the Appendix). Our findings remain robust to this specification test.

Taken together, our results provide strong support for our theoretical explanation and hypotheses. However, our results cannot provide evidence of a causal effect because we do not have panel information and therefore cannot entirely rule out reverse causality. 


\section{Conclusion}

The German Codetermination Law grants the right to a paid leave of absence to a works councillor in establishments with 200 or more employees. In our paper, we add to the literature in showing that legal regulations do not automatically guarantee that granted rights are actually effective. Our theoretical analysis is based on a combination of the work by Freeman and Lazear (1995) on works council effects on the one hand and Kotthoff's (1981, 1994) work on different types of employment relations on the other, supplemented by additionally taking into account of a potential leverage effect with respect to firm size. While Freeman and Lazear do not elaborate on the conditions under which allocative effects might be particularly strong and distributive effects only weak (or vice versa), combining the work by Freeman and Lazear with the one from Kotthoff allows us to do so: Specifically, we argue that in cooperative employment relations, allocative effects will be rather strong and distributive effects rather weak, while in adversarial employment relations it will be the other way around. Taking further account of a potential leverage effect with increasing firm size, allows us to derive our hypotheses on the exemption of works councillors in cooperative vs. adversarial employment relations below or above the legal threshold.

In our empirical analysis, we find that whether codetermination regulation has an effect crucially depends on the nature of the employment relations participation regime, with regulation primarily affecting firms where employment relations are adversarial. In firms with cooperative employment relations, to the contrary, the probability of works councillor exemption steadily increases with firm size and remains unaffected by the legal threshold hinting that a general leverage effect, rather than legal forces, is at work. Thus, although the exemption regulation has no effect in cooperative employment relations it does develop bite in adversarial relations, i.e., when the legislators' intent would not be realised without the 
right to legal enforcement. Voluntarism is fine in many circumstances because firms grant workers' rights in their own interest or because the parties act in "the shadow of the law" (Bercusson 1994). In adversarial employment relations, however, the "bite” of an enforceable law strengthen workers' rights (if that is what the legislator wants).Concerning practical implications from our analysis, the general message to the legislator (also in other industrial relations systems outside Germany and on supranational level) is that legal regulations strengthening workers' rights (e.g. the European Works Council EWC) will only bite in adversarial employment relations. Further, concerning practitioners, our study shows that for employers and employee representatives it might in fact pay to invest in cooperative employment relations because, in general, both parties will be better off: The rent will increase and so will the share that goes to the employer and the one that goes to the workers. In an adversarial situation where confrontations cannot be avoided, however, the legally enforced exemption of works councillors will strengthen workers’ rights and make sure that workers get their fair share when it comes to the distribution of the rent. However, even in such a situation, it will pay the parties to try to work in the direction of an increased cooperation, because this might start a self-reinforcing process of increasing rents and increasing shares for both parties. Here, consultants and unions might play an important role as they are not immediately involved in adversarial relations’ daily workplace struggles.

Concerning implications for future studies, our study supports the claim put forward by Jirjahn and Smith (2006: 650) concerning the potential shortcomings of failing to differentiate between cooperative and uncooperative employment relations participation regimes. Hence, much of the literature on works councils must be revisited because the measured effects may be invalidated if different employment relations participation regimes are taken into account. The previous literature could not distinguish between different employment relations regimes due to data limitations; our results, however, show that variations in em- 
ployment relations regimes are very important because the effects that we find are very different for different employment relations participation regimes. Thus, future research should address this problem by (a) theoretically distinguishing between different regimes and (b) empirically taking different regimes into account, e.g., by systematically including questions on the nature of the underlying employment relations participation regime in surveys.

\section{References}

Addison, J. T., Schnabel, C. and Wagner, J. (1997). On the determinants of mandatory works councils in Germany. Industrial Relations, 36: 419-445.

Addison, J. T., Schnabel, C. and Wagner, J. (2001). Works councils in Germany: their effects on establishment performance. Oxford Economic Papers, 53: 659-694.

Addison, J. T., Schnabel, C. and Wagner, J. (2004). The course of research into the economic consequences of German works councils. British Journal of Industrial Relations, 42: 255-281.

Bercusson, B. (1994). The dynamic of European labour law after Maastricht. Industrial Law Journal, 23:1-31.

Bryson, A., Forth, J., Laroche, P. (2011). Evolution or revolution? The impact of unions on workplace performance in Britain and France. European Journal of Industrial Relations, 17: 171-187.

Dilger, A. (2002). Ökonomik betrieblicher Mitbestimmung. Die wirtschaftlichen Folgen von Betriebsräten. München/Mering.

Dilger, A. (2006). Kooperation zwischen Betriebsrat und Management. Die Sicht beider Seiten und deren Folgen. Jahrbücher für Nationalökonomie und Statistik, 226: 562-587. 
Freeman, R. B. and Lazear, E. P. (1995). An economic analysis of works councils. In J. Rogers and W. Streeck (eds.), Works Councils: Consultation, Representation, and Cooperation in Industrial Relations. Chicago/London, pp. 27-50.

Friedrich, W. and Hägele, H. (1997). Ökonomische Konsequenzen von Schwellenwerten im Arbeits- und Sozialrecht sowie die Auswirkungen dieser Regelungen. Studien der ISG Sozialforschung und Gesellschaftspolitik. Bd. 20, Cologne.

Hann, D. and Teague, P. (2012). The Changing Role of Employment Tribunals: The Case of the Employment Appeals Tribunal in Ireland. Economic and Industrial Democracy. 33: 531-549.

Helfen, M. and Schuessler, M.S. (2009). Uncovering Divergence: Management Attitudes towards HRM Practices and Works Council Presence in German SMEs. In: Economic and Industrial Democracy, 30: 207-240.

Heywood, J. S. and Jirjahn, U. (2009a). Family friendly practices and worker representation in Germany.” Industrial Relations, 48: 121-145.

Heywood, J. S. and Jirjahn, U. (2009b). Profit sharing and firm size: the role of team production. Journal of Economic Behavior \& Organization, 71: 246-258.

Hirsch, B., Schank, T. and Schnabel, C. (2010). Works councils and separations: voice, monopoly, and insurance effects. Industrial Relations, 49: 566-592.

Hübler, O. and Jirjahn, U. (2003). Works councils and collective bargaining in Germany: the impact on productivity and wages. Scottish Journal of Political Economy, 50: 471491.

Jirjahn, U. (2009). The introduction of works councils in German establishments - rent seeking or rent protection? British Journal of Industrial Relations, 47: 521-545. 
Jirjahn, U. and Smith, S. C. (2006). What factors lead management to support or oppose employee participation - with and without works councils? Hypotheses and evidence from Germany. Industrial Relations, 45: 650-680.

Koller, L., Schnabel, C. and Wagner, J. (2008). Freistellung von Betriebsräten - eine beschäftigungsbremse? Zeitschrift für Arbeitsmarktforschung, 41: 305-326.

Kotthoff, H. (1981). Betriebsräte und Betriebliche Herrschaft: Eine Typologie von Partizipationsmustern im Industriebetrieb. Frankfurt: Campus Verlag.

Kotthoff, H. (1994). Betriebsräte und Bürgerstatus: Wandel und Kontinuität betrieblicher Mitbestimmung. München/Mering.

Marsden, D. (2012). Individual voice in employment relationships: a comparison under different forms of workplace representation. Industrial Relations (in press).

Mohrenweiser, J. and Backes-Gellner, U. (2010). Die Wirkung des Betriebsverfassungsgesetzes am Beispiel der Freistellung von Betriebsräten - ein Beitrag zur Rechtstatsachenforschung. Jahrbücher für Nationalökonomie und Statistik, 230: 420-435.

Mohrenweiser, J., Marginson, P. and Backes-Gellner, U. (2012). What triggers the establishment of a works council? Economic and Industrial Democracy, 33: 295-316.

Mueller, S. (2011). Works Councils and Firm Profits Revisited. British Journal of Industrial Relations, 49: s27-s43.

Nienhueser, W. (2009). The Effects of Different Types of Works Councils on Bargaining Outcomes: Results of an Empirical Study. Economic and Industrial Democracy, 30: 372400.

Pfeifer, C. (2011a). Works Councils, Union Bargaining, and Quits in German Firms. Economic and Industrial Democracy, 32: 243-260.

Pfeifer, C. (2011b). The Heterogeneous Economic Consequences of Works Council Relations. Schmollers Jahrbuch, 131: 59-71. 
Rolfsen, M. (2011). How close can we dance? Labour-management partnership on a borderline. Economic and Industrial Democracy, 32: 591-608.

Schlömer, N., Kay, R. Backes-Gellner, U., Rudolph, W. and Wassermann, W. (2007). Mittelstand und Mitbestimmung Unternehmensführung, Mitbestimmung und Beteiligung in mittelständischen Unternehmen. Münster: Westfälisches Dampfboot.

Schnabel, C. and Wagner, J. (2001). Die betriebsratsfreie Zone und die Novellierung des Betriebsverfassungsgesetzes aus ökonomischer Sicht. Theoretische Überlegungen und empirische Befunde. Gewerkschaftliche Monatshefte, 52: 237-243. 


\section{Appendix}

Table A1: Robustness Checks

\begin{tabular}{|c|c|c|c|c|c|}
\hline & $\begin{array}{l}\text { All } \\
\text { Firms } \\
\text { (1) }\end{array}$ & $\begin{array}{l}\text { All } \\
\text { Firms } \\
(2)\end{array}$ & $\begin{array}{l}\text { All } \\
\text { Firms } \\
\text { (3) }\end{array}$ & $\begin{array}{c}\text { Good } \\
\text { Relations } \\
\text { (4) }\end{array}$ & $\begin{array}{c}\text { Good } \\
\text { Relations } \\
\text { (5) }\end{array}$ \\
\hline 200+ Employees & $\begin{array}{l}0.315 \\
(0.69)\end{array}$ & $\begin{array}{l}0.150 \\
(0.37)\end{array}$ & $\begin{array}{l}0.161 \\
(0.35)\end{array}$ & $\begin{array}{l}3.072 \\
(0.69) \\
\end{array}$ & $\begin{array}{c}6.126 \\
(1.04) \\
\end{array}$ \\
\hline LnSize & $\begin{array}{c}2.208 * * * \\
(4.30)\end{array}$ & $\begin{array}{c}1.938 * * * \\
(4.54)\end{array}$ & $\begin{array}{c}2.170 * * * \\
(4.36)\end{array}$ & $\begin{array}{c}2.136^{* *} \\
(3.23) \\
\end{array}$ & $\begin{array}{c}2.652 * * \\
(2.67) \\
\end{array}$ \\
\hline 200+ Employees * $\ln S i z e$ & & & & $\begin{array}{c}-0.546 \\
(0.64) \\
\end{array}$ & $\begin{array}{c}-1.100 \\
(0.96) \\
\end{array}$ \\
\hline Bad Employment Relations & $\begin{array}{l}-0.647 \\
(1.42) \\
\end{array}$ & $\begin{array}{l}-0.021 \\
(0.07)\end{array}$ & $\begin{array}{l}-0.067 \\
(0.20)\end{array}$ & & \\
\hline Good Employment Relations & $\begin{array}{l}-0.413 \\
(1.22)\end{array}$ & & & & \\
\hline Skilled Employees & $\begin{array}{l}-0.212 \\
(0.33)\end{array}$ & & $\begin{array}{l}-0.284 \\
(0.46)\end{array}$ & & $\begin{array}{l}-0.634 \\
(0.94)\end{array}$ \\
\hline Apprentices & $\begin{array}{l}-1.803 \\
(1.06) \\
\end{array}$ & & $\begin{array}{l}-0.625 \\
(0.42) \\
\end{array}$ & & $\begin{array}{l}-0.336 \\
(0.19) \\
\end{array}$ \\
\hline Part-Time Employees & $\begin{array}{l}0.429 \\
(0.96) \\
\end{array}$ & & $\begin{array}{l}0.347 \\
(0.93) \\
\end{array}$ & & $\begin{array}{l}0.398 \\
(1.00) \\
\end{array}$ \\
\hline Female Employees & $\begin{array}{l}-1.328 \\
(1.94) \\
\end{array}$ & & $\begin{array}{l}-1.077 \\
(1.62) \\
\end{array}$ & & $\begin{array}{c}-1.852^{*} \\
(2.49) \\
\end{array}$ \\
\hline Employment Growth & $\begin{array}{l}-0.280 \\
(0.92) \\
\end{array}$ & & $\begin{array}{l}-0.254 \\
(0.88) \\
\end{array}$ & & $\begin{array}{l}-0.116 \\
(0.39) \\
\end{array}$ \\
\hline Collective Agreement & $\begin{array}{l}0.564^{*} \\
(2.00)\end{array}$ & & & & \\
\hline Active Owner & $\begin{array}{l}0.020 \\
(0.07) \\
\end{array}$ & & $\begin{array}{l}0.013 \\
(0.05)\end{array}$ & & $\begin{array}{l}-0.054 \\
(0.17)\end{array}$ \\
\hline Direct Participation & $\begin{array}{l}0.338 \\
(1.19) \\
\end{array}$ & & & & \\
\hline Strong Support by Workforce & $\begin{array}{l}-0.263 \\
(0.84) \\
\end{array}$ & & & & \\
\hline Strong Influence of Unions & $\begin{array}{l}0.253 \\
(0.89) \\
\end{array}$ & & & & \\
\hline Age of Works Council & $\begin{array}{l}0.004 \\
(0.48) \\
\end{array}$ & & & & \\
\hline East Germany & $\begin{array}{l}0.329 \\
(0.99)\end{array}$ & & $\begin{array}{l}0.085 \\
(0.30)\end{array}$ & & $\begin{array}{l}0.083 \\
(0.25)\end{array}$ \\
\hline Industry Dummies & yes & Yes & yes & yes & yes \\
\hline Constant & $\begin{array}{c}-12.77^{* * *} * \\
(4.41)\end{array}$ & $\begin{array}{c}-11.09 * * * \\
(5.26)\end{array}$ & $\begin{array}{c}-11.98^{* * *} \\
(4.35) \\
\end{array}$ & $\begin{array}{c}-12.05^{* * *} \\
(3.68) \\
\end{array}$ & $\begin{array}{c}-14.06 * * \\
(2.67) \\
\end{array}$ \\
\hline Pseudo R-sqr & 0.47 & 0.39 & 0.44 & 0.37 & 0.43 \\
\hline Observations & 231 & 231 & 231 & 206 & 206 \\
\hline
\end{tabular}

Coefficients of a Probit ML estimation. Robust Z-statistics are in parentheses. *** Statistically significant at $1 \%$; ** statistically significant at $5 \%$; * statistically significant at $10 \%$.

Source: IfM Bonn Works Council Survey 2005. 
Table A2: Distribution of Managerial Valuation of the Management - Works Council Relation

\begin{tabular}{|l|c|c|}
\hline & Frequency & $\%$ \\
\hline Very Bad & 2 & 0.86 \\
\hline Bad & 23 & 9.95 \\
\hline Neutral & 49 & 21.21 \\
\hline Good & 117 & 50.65 \\
\hline Very Good & 40 & 17.32 \\
\hline Total & 231 & 100 \\
\hline
\end{tabular}

Source: IfM Bonn Works Council Survey 2005. 
Table A3: Sample Selection Model $^{8}$, Two-Stage Least Square Estimation

\begin{tabular}{|c|c|c|c|}
\hline & $\begin{array}{c}\text { All Firms } \\
\text { (1) }\end{array}$ & $\begin{array}{c}\text { All Firms } \\
\text { First Stage } \\
\text { (2) }\end{array}$ & $\begin{array}{c}\text { All Firms } \\
\text { Second Stage } \\
\text { (3) }\end{array}$ \\
\hline 200+ Employees & $\begin{array}{l}0.148 \\
(0.33)\end{array}$ & $\begin{array}{l}0.015 \\
(0.03) \\
\end{array}$ & $\begin{array}{l}0.313 \\
(1.34) \\
\end{array}$ \\
\hline LnSize & $\begin{array}{c}2.232 * * * \\
(4.45) \\
\end{array}$ & $\begin{array}{c}2.004^{* * * *} \\
(3.45) \\
\end{array}$ & $\begin{array}{c}0.581 * * * \\
(4.76)\end{array}$ \\
\hline Skilled Employees & $\begin{array}{l}-0.324 \\
(-0.51) \\
\end{array}$ & $\begin{array}{l}-0.440 \\
(-0.71) \\
\end{array}$ & $\begin{array}{c}0.765^{* *} \\
(2.65) \\
\end{array}$ \\
\hline Apprentices & $\begin{array}{l}-1.123 \\
(-0.68)\end{array}$ & $\begin{array}{l}-1.054 \\
(-0.48)\end{array}$ & $\begin{array}{l}0.304 \\
(0.37)\end{array}$ \\
\hline Part-Time Employees & $\begin{array}{l}0.255 \\
(0.61)\end{array}$ & $\begin{array}{l}0.189 \\
(0.41)\end{array}$ & $\begin{array}{l}0.284 \\
(1.35)\end{array}$ \\
\hline Female Employees & $\begin{array}{l}-1.154 \\
(-1.74) \\
\end{array}$ & $\begin{array}{l}-0.949 \\
(-1.33) \\
\end{array}$ & $\begin{array}{l}-0.301 \\
(-1.06) \\
\end{array}$ \\
\hline Employment Growth & $\begin{array}{l}-0.258 \\
(-0.91) \\
\end{array}$ & $\begin{array}{l}-0.168 \\
(-0.59) \\
\end{array}$ & $\begin{array}{c}-0.407 * * \\
(-2.86) \\
\end{array}$ \\
\hline Collective Agreement & $\begin{array}{l}0.579 * \\
(2.17) \\
\end{array}$ & $\begin{array}{l}0.378 \\
(1.14) \\
\end{array}$ & $\begin{array}{c}0.728 * * * \\
(5.41) \\
\end{array}$ \\
\hline Active Owner & $\begin{array}{l}0.155 \\
(0.53) \\
\end{array}$ & $\begin{array}{l}0.379 \\
(1.13) \\
\end{array}$ & $\begin{array}{c}-1.089 * * * \\
(-7.66)\end{array}$ \\
\hline Direct Participation & $\begin{array}{l}0.282 \\
(1.05) \\
\end{array}$ & $\begin{array}{l}0.229 \\
(0.85) \\
\end{array}$ & $\begin{array}{l}0.064 \\
(0.45) \\
\end{array}$ \\
\hline East Germany & $\begin{array}{l}0.240 \\
(0.80) \\
\end{array}$ & $\begin{array}{l}0.199 \\
(0.57) \\
\end{array}$ & $\begin{array}{l}0.069 \\
(0.43) \\
\end{array}$ \\
\hline Mills Ratio & & & $\begin{array}{l}-0.660 \\
(-0.98) \\
\end{array}$ \\
\hline Constant & $\begin{array}{c}-12.89 * * * \\
(-4.54)\end{array}$ & $\begin{array}{c}-11.23 * * * \\
(-3.33)\end{array}$ & $\begin{array}{c}-2.71 * * * \\
(-4.28)\end{array}$ \\
\hline Industry Dummies & yes & yes & yes \\
\hline Pseudo R-sqr/ LogLikelihood & 0.46 & -314.217 & \\
\hline Number of Observations & 231 & 570 & 231 \\
\hline
\end{tabular}

Column 1 repeats the estimation of Table 2 without variables that are not observed in firms without a works council. Columns 2 and 3 show the first and second stages of a Heckman-type selection correction model identifying the selection effect with the functional form.

Coefficients of a Probit ML estimation. Robust Z-statistics are in parentheses. *** Statistically significant at $1 \%$; ** statistically significant at 5\%; * statistically significant at $10 \%$. Source: IfM Bonn Works Council Survey 2005. 
Table 1: Variable Definitions and Descriptive Statistics ( $\mathrm{N}=231)$

\begin{tabular}{|c|c|}
\hline Variable & Description (Mean, Std. Dev.) \\
\hline $\begin{array}{l}\text { Works Councillor } \\
\text { Exemption }\end{array}$ & $\begin{array}{l}\text { Dummy variable equal to } 1 \text { if at least one works councillor is } \\
\text { fully exempted from his or her regular duties }(0.247,0.432) \text {. }\end{array}$ \\
\hline 200+ Employees & $\begin{array}{l}\text { Dummy variable equal to } 1 \text { if the establishment employs more } \\
\text { than } 200 \text { employees }(0.432,0.496) \text {. }\end{array}$ \\
\hline LnSize & $\begin{array}{l}\text { Log of the number of total employees in the establishment } \\
(4.973,0.769) \text {. }\end{array}$ \\
\hline $\begin{array}{l}\text { Bad Employment } \\
\text { Relations }\end{array}$ & $\begin{array}{l}\text { Dummy variable equal to } 1 \text { if management views the relation- } \\
\text { ship with the works council as being very bad or bad }(0.108 \text {, } \\
0.311) \text {. }\end{array}$ \\
\hline Skilled Employees & $\begin{array}{l}\text { Employees with a university or apprenticeship degree as a pro- } \\
\text { portion of total employees }(0.776,0.218) \text {. }\end{array}$ \\
\hline Apprentices & Apprentices as a proportion of total employees $(0.052,0.072)$. \\
\hline Part-time Employees & $\begin{array}{l}\text { Part-time employees as a proportion of total employees }(0.217 \text {, } \\
0.314) \text {. }\end{array}$ \\
\hline Female Employees & Women as a proportion of total employees $(0.349,0.248)$. \\
\hline Employment Growth & $\begin{array}{l}\text { Dummy variable equal to } 1 \text { if the establishment experienced a } \\
\text { positive employment growth during the last three years }(0.281 \text {, } \\
0.451) \text {. }\end{array}$ \\
\hline Collective Agreement & $\begin{array}{l}\text { Dummy variable equal to } 1 \text { if the establishment is covered by a } \\
\text { collective bargaining agreement }(0.615,0.488) \text {. }\end{array}$ \\
\hline Active Owner & $\begin{array}{l}\text { Dummy variable equal to } 1 \text { if the establishment is managed by } \\
\text { an active owner }(0.351,0.478) .\end{array}$ \\
\hline Direct Participation & $\begin{array}{l}\text { Dummy variable equal to } 1 \text { if there are other direct forms of } \\
\text { worker involvement in decision making }(0.429,0.496) \text {. }\end{array}$ \\
\hline $\begin{array}{l}\text { Strong Support by } \\
\text { Workforce }\end{array}$ & $\begin{array}{l}\text { Dummy variable equal to } 1 \text { if the workforce strongly supports } \\
\text { the works council }(0.268,0.444) \text {. }\end{array}$ \\
\hline Strong Union Influence & $\begin{array}{l}\text { Dummy variable equal to } 1 \text { if unions have strong influence on } \\
\text { the works council }(0.430,0.497) \text {. }\end{array}$ \\
\hline Age of Works Council & $\begin{array}{l}\text { Time span between the survey year and the year the works } \\
\text { council has been introduced }(19.43,16.38) \text {. }\end{array}$ \\
\hline East Germany & $\begin{array}{l}\text { Dummy variable equal to } 1 \text { if the establishment is located in } \\
\text { East Germany }(0.225,0.419) \text {. }\end{array}$ \\
\hline Industry Dummies & $\begin{array}{l}\text { Industry dummies for manufacturing, construction, retail, logis- } \\
\text { tics \& communication, services for companies, and services for } \\
\text { private individuals }\end{array}$ \\
\hline
\end{tabular}


Table 2: Determinants of Works Councillor Exemption - All Establishments and Establishments with Good Relations

\begin{tabular}{|c|c|c|c|c|}
\hline & $\begin{array}{c}\text { All } \\
\text { Firms } \\
\text { (I) }\end{array}$ & $\begin{array}{c}\text { Good } \\
\text { Relations } \\
\text { (II) }\end{array}$ & $\begin{array}{c}\text { Good } \\
\text { Relations } \\
\text { (III) }\end{array}$ & $\begin{array}{c}\text { Good } \\
\text { Relations } \\
\text { (IV) }\end{array}$ \\
\hline 200+ Employees & $\begin{array}{l}0.248 \\
(0.55)\end{array}$ & & $\begin{array}{l}0.539 \\
(1.16)\end{array}$ & $\begin{array}{l}6.969 \\
(1.27)\end{array}$ \\
\hline LnSize & $\begin{array}{l}2.185^{* * *} \\
(4.26)\end{array}$ & $\begin{array}{l}2.224^{* * *} \\
(6.88)\end{array}$ & $\begin{array}{c}1.806^{* * *} \\
(3.73)\end{array}$ & $\begin{array}{c}2.714 * * * \\
(3.02)\end{array}$ \\
\hline 200+ Employees * LnSize & & & & $\begin{array}{l}-1.239 \\
(1.17)\end{array}$ \\
\hline $\begin{array}{l}\text { Bad Employment } \\
\text { Relations }\end{array}$ & $\begin{array}{l}-0.375 \\
(0.98)\end{array}$ & & & \\
\hline Skilled Employees & $\begin{array}{l}-0.236 \\
(0.37)\end{array}$ & $\begin{array}{l}-0.370 \\
(0.54)\end{array}$ & $\begin{array}{l}-0.463 \\
(0.66)\end{array}$ & $\begin{array}{l}-0.528 \\
(0.74)\end{array}$ \\
\hline Apprentices & $\begin{array}{l}-1.733 \\
(1.01)\end{array}$ & $\begin{array}{l}-1.394 \\
(0.76)\end{array}$ & $\begin{array}{l}-1.331 \\
(0.72)\end{array}$ & $\begin{array}{l}-1.404 \\
(0.74)\end{array}$ \\
\hline Part-Time Employees & $\begin{array}{l}0.382 \\
(0.88)\end{array}$ & $\begin{array}{l}0.414 \\
(0.98)\end{array}$ & $\begin{array}{l}0.382 \\
(0.91)\end{array}$ & $\begin{array}{l}0.436 \\
(0.98)\end{array}$ \\
\hline Female Employees & $\begin{array}{c}-1.173^{*} \\
(1.78)\end{array}$ & $\begin{array}{c}-1.698 * * \\
(2.38)\end{array}$ & $\begin{array}{c}-1.782^{* *} \\
(2.44)\end{array}$ & $\begin{array}{c}-1.920^{* *} \\
(2.57)\end{array}$ \\
\hline Employment Growth & $\begin{array}{l}-0.295 \\
(0.99)\end{array}$ & $\begin{array}{l}-0.138 \\
(0.45)\end{array}$ & $\begin{array}{l}-0.166 \\
(0.55)\end{array}$ & $\begin{array}{l}-0.156 \\
(0.51)\end{array}$ \\
\hline Collective Agreement & $\begin{array}{l}0.534^{*} \\
(1.92)\end{array}$ & $\begin{array}{l}0.548 \\
(1.85)\end{array}$ & $\begin{array}{l}0.554^{*} \\
(1.86)\end{array}$ & $\begin{array}{l}0.542^{*} \\
(1.78)\end{array}$ \\
\hline Active Owner & $\begin{array}{l}0.083 \\
(0.28)\end{array}$ & $\begin{array}{l}0.106 \\
(0.35)\end{array}$ & $\begin{array}{l}0.035 \\
(0.11)\end{array}$ & $\begin{array}{l}0.023 \\
(0.07)\end{array}$ \\
\hline Direct Participation & $\begin{array}{l}0.329 \\
(1.18)\end{array}$ & $\begin{array}{l}0.224 \\
(0.76)\end{array}$ & $\begin{array}{l}0.230 \\
(0.78)\end{array}$ & $\begin{array}{l}0.220 \\
(0.75)\end{array}$ \\
\hline Strong Support by Workforce & $\begin{array}{l}-0.348 \\
(1.16)\end{array}$ & $\begin{array}{l}-0.291 \\
(0.98)\end{array}$ & $\begin{array}{l}-0.328 \\
(1.11)\end{array}$ & $\begin{array}{l}-0.339 \\
(1.14)\end{array}$ \\
\hline Strong Union Influence & $\begin{array}{l}0.311 \\
(1.12)\end{array}$ & $\begin{array}{l}0.299 \\
(1.04)\end{array}$ & $\begin{array}{l}0.331 \\
(1.15)\end{array}$ & $\begin{array}{l}0.368 \\
(1.25)\end{array}$ \\
\hline Age of Works Council & $\begin{array}{l}0.004 \\
(0.44)\end{array}$ & $\begin{array}{l}0.002 \\
(0.26)\end{array}$ & $\begin{array}{l}0.002 \\
(0.19)\end{array}$ & $\begin{array}{l}0.003 \\
(0.27)\end{array}$ \\
\hline East Germany & $\begin{array}{l}0.365 \\
(1.15)\end{array}$ & $\begin{array}{l}0.265 \\
(0.76)\end{array}$ & $\begin{array}{l}0.290 \\
(0.83)\end{array}$ & $\begin{array}{l}0.332 \\
(0.90)\end{array}$ \\
\hline Industry Dummies & Yes & Yes & Yes & Yes \\
\hline Constant & $\begin{array}{c}- \\
12.905^{* * *} \\
(4.46)\end{array}$ & $\begin{array}{c}- \\
12.763^{* * *} \\
(6.05)\end{array}$ & $\begin{array}{c}- \\
10.742 * * * \\
(3.95)\end{array}$ & $\begin{array}{c}- \\
15.228 * * * \\
(3.13)\end{array}$ \\
\hline Pseudo R-sqr & 0.47 & 0.46 & 0.46 & 0.47 \\
\hline Observations & 231 & 206 & 206 & 206 \\
\hline
\end{tabular}

Coefficients of a Probit ML estimation. Robust Z-statistics are in parentheses.

*** Statistically significant at $1 \%$; ** statistically significant at $5 \%$; * statistically significant at $10 \%$. Source: IfM Bonn Works Council Survey 2005. 
Table 3: Establishments with Bad Relations and Works Councillor Exemption

\begin{tabular}{lccc}
\hline & $\begin{array}{c}\text { Less than } \\
\text { 200 Employees }\end{array}$ & $\begin{array}{c}\text { More than } \\
\text { 200 Employees }\end{array}$ & Total \\
\hline No Paid Leaves of Absence & 13 & 5 & 18 \\
Paid leaves of absence & 0 & 7 & 7 \\
\hline Total & 13 & 12 & 25
\end{tabular}

Source: IfM Bonn Works Council Survey.

Table 4: Determinants of Works Councillor Exemption - Establishments with Bad Relations above Legal Threshold

\begin{tabular}{|l|l|}
\hline LnSize & $\begin{array}{l}6.226^{* *} \\
(2.40)\end{array}$ \\
\hline Constant & $-35.443^{* *}$ \\
& $(2.40)$ \\
\hline Pseudo R-sqr & 0.46 \\
\hline Observations & 12 \\
\hline
\end{tabular}

Coefficients of a Probit ML estimation. Robust Z-statistics are in parentheses.

*** Statistically significant at 1\%; ** statistically significant at 5\%; * statistically significant at $10 \%$.

Source: IfM Bonn Works Council Survey 2005. 
Table 5: Determinants of Works Councillor Exemption, Establishments with Good Relations - Robustness Checks

\begin{tabular}{|l|c|c|c|c|c|c|}
\hline & (I) & (II) & (III) & (IV) & (V) & (VI) \\
\hline 200+ Employees & & 0.163 & & & -0.068 & $2.087^{* * *}$ \\
& & $(0.31)$ & & & $(-0.13)$ & $(7.48)$ \\
\hline LnSize & $23.301^{* *}$ & $\begin{array}{c}21.181^{*} \\
(2.13)\end{array}$ & & & & \\
\hline LnSize squared / 1000 & $-1.925^{*}$ & -1.745 & & & & \\
\hline Firm Size & $(-1.95)$ & $(-1.63)$ & & & & \\
\hline Firm Size squared / 1000 & & & $0.009^{* * *}$ & $0.037^{* * *}$ & $0.038^{* * *}$ & \\
& & & $(7.40)$ & $(4.73)$ & $(3.49)$ & \\
\hline Controls & & & & $-0.051^{* * *}$ & $-0.053^{* * *}$ & \\
\hline Pseudo R-sqr & Yes & Yes & Yes & Yes & Yes & Yes \\
\hline Number of Observations & 206 & 206 & 206 & 206 & 206 & 206 \\
\hline
\end{tabular}

We use the same control variables as in the regressions of Table 2 column (II) to (IV).

Coefficients of a Probit ML estimation. Robust Z-statistics are in parentheses.

*** Statistically significant at $1 \%$; ** statistically significant at $5 \%$; * statistically significant at $10 \%$.

Source: IfM Bonn Works Council Survey 2005. 
Figure 1: Employer Rent and Firm Size in Cooperative vs. Adversarial Employment Relations

Panel A: cooperative

Total Rent per Employee

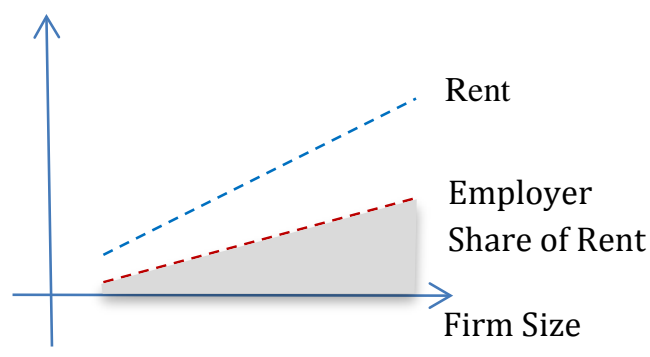

Panel B: adversarial

Total Rent per Employee

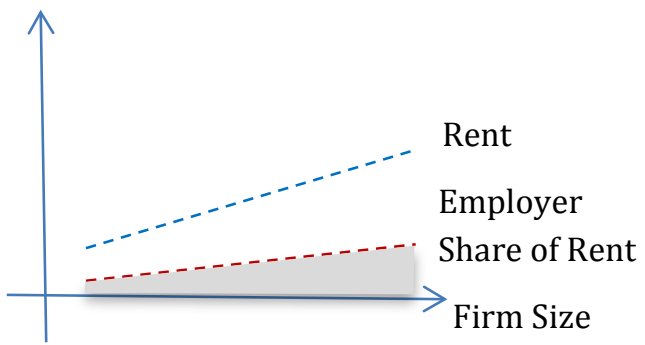

Figure 2: The Effect of Exemption in Cooperative vs. Adversarial Employment Relations

Panel A: cooperative

Total Rent per Employee

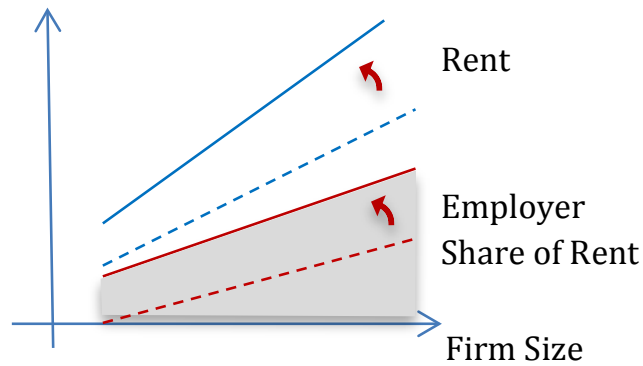

Panel B: adversarial

Total Rent per Employee

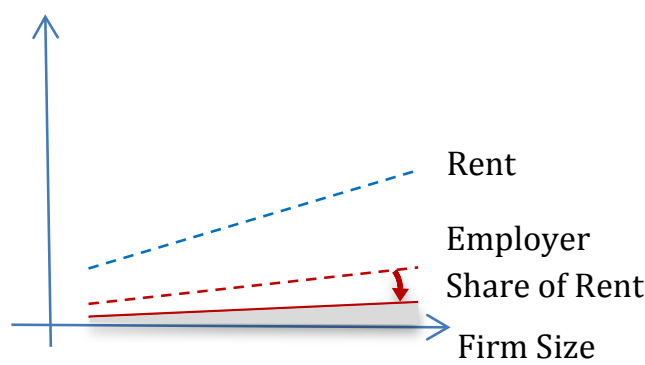


Figure 3: Expected Probability Pattern of Exemptions in Adversarial Employment Relations (H1).

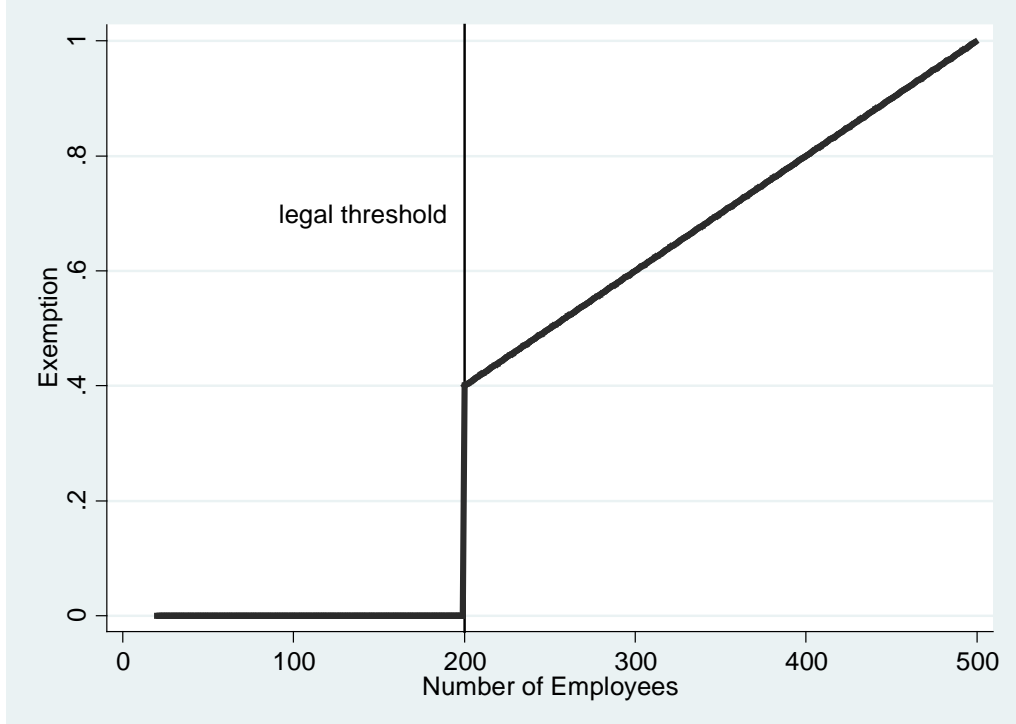

Figure 4: Expected Probability Pattern of Exemptions in Cooperative Employment Relations (H2).

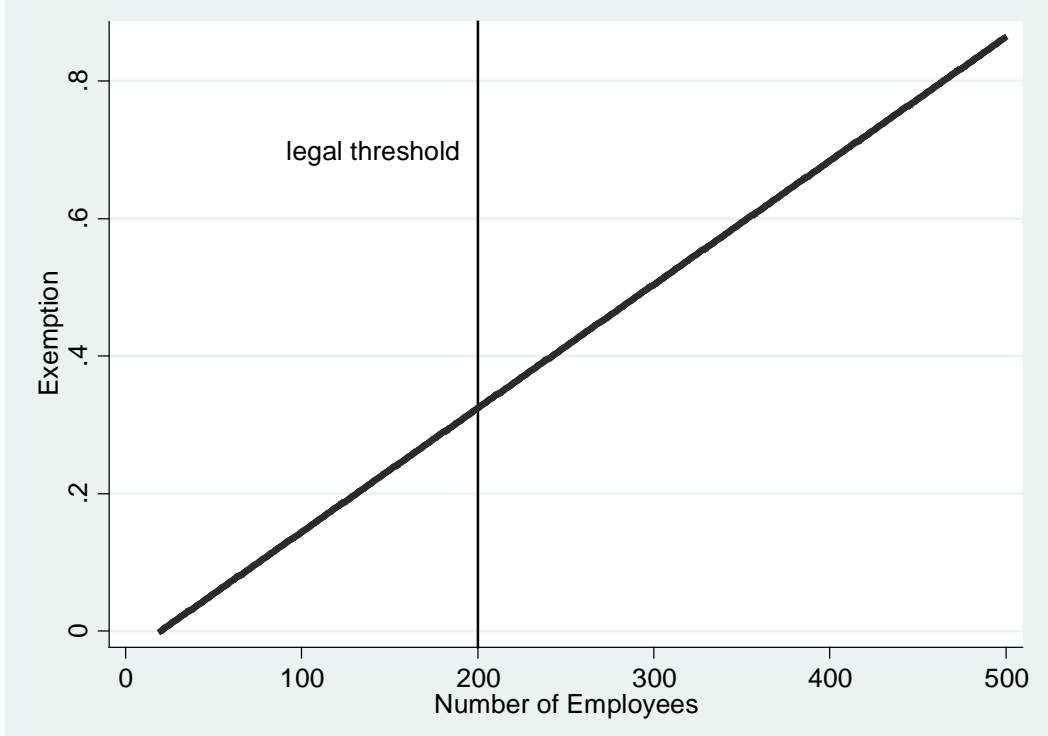


Figure 5: Works Councillor Exemption - Predicted Probabilities.

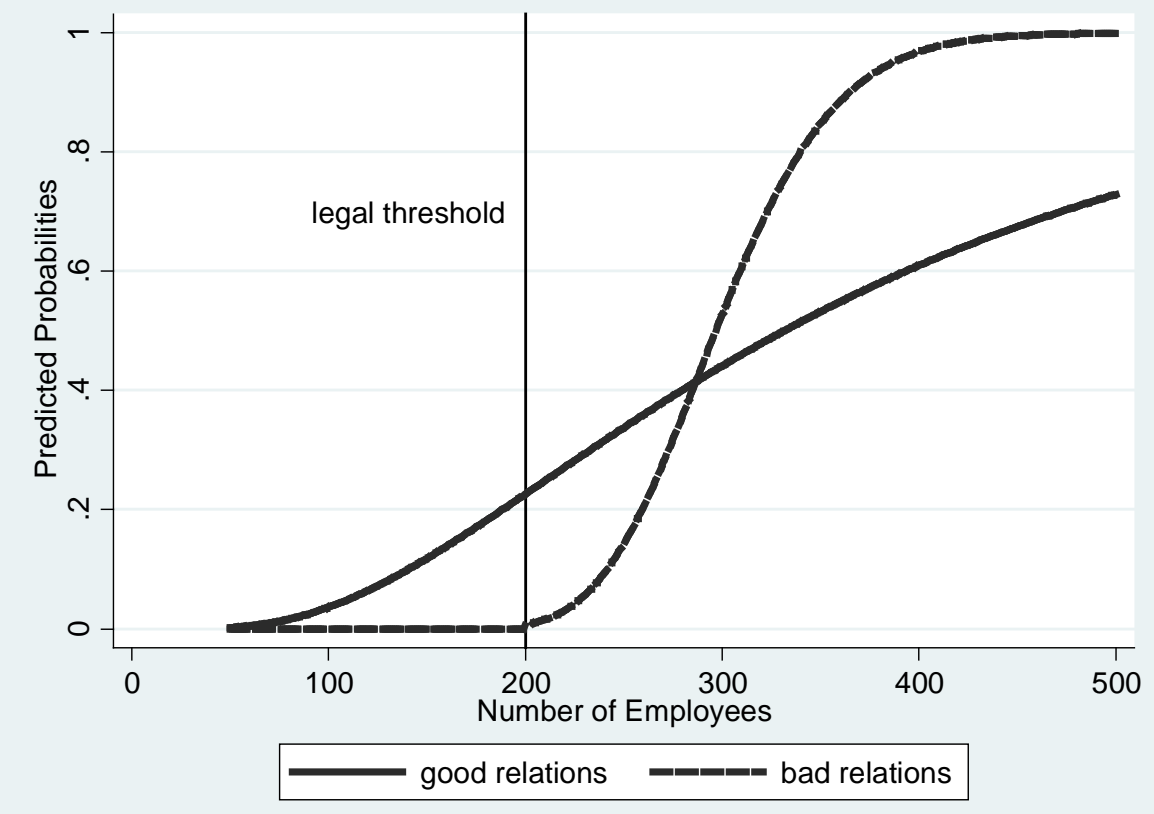

The predicted probabilities of works councillor exemption for establishments with good relations are predicted by using the estimated coefficients in column (III) of Table 2 . The probabilities for establishments with bad relations are predicted using the estimated coefficients of Table 4 . All of the other control variables are assumed to be at their mean levels. $\mathrm{N}=231$.

Source: IfM Bonn Works Council Survey. 
Figure 6: Proportion of Establishments with Works Councillor Exemption

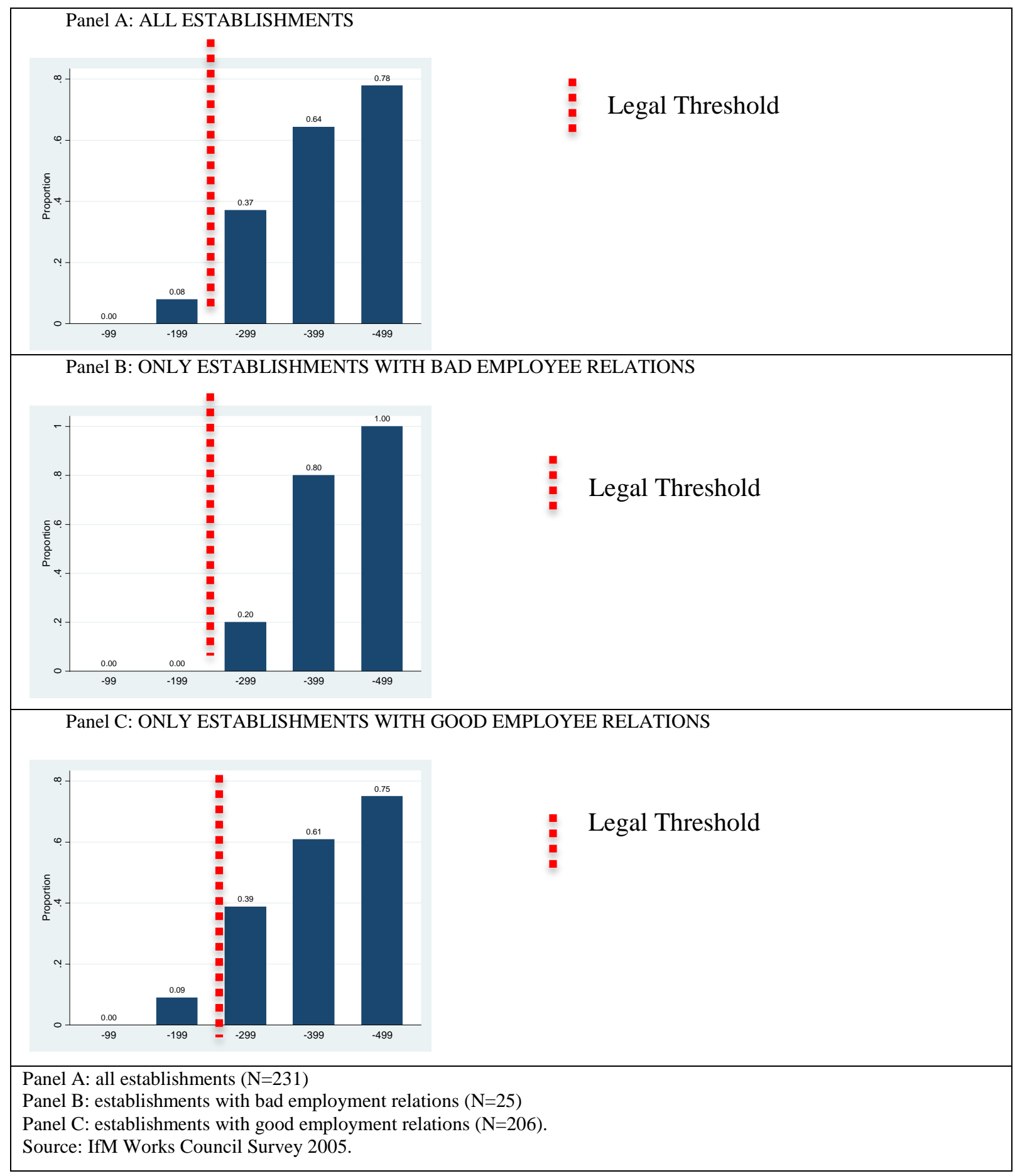

